\title{
腎細胞癌患者の養子免疫療法に関する研究
}

第 1 編：腎細胞癌患者の末梢血単核球機能

および血中免疫抑制因子

広島大学医学部泌尿器科学教室 (主任：碓井 亞教授)

薄 井 昭 博

\section{STUDY ON ADOPTIVE IMMUNOTHERAPY ON PATIENTS WITH RENAL CELL CARCINOMA}

I. Functional Characteristics of Peripheral Blood Mononuclear

Cells and Serum Immunosuppressive Factors in

Patients with Renal Cell Carcinoma

\author{
Akihiro Usui \\ Department of Urology, Hiroshima University School of Medicine, Hiroshima \\ (Direcotor: Prof. T. Usui)
}

The immune responses in patients with renal cell carcinoma were evaluated from the production of interleukin-2 (IL-2), the expression of IL-2 receptors and the activity of lymphokine activated killer (LAK) cells. In addition, the effect of the patient's serum on the expression of IL-2 receptors and LAK activity were investigated.

The production of IL-2 by peripheral blood mononuclear cells (PBM) from patients with renal cell carcinoma was not suppressed, when compared with that in controls. However, the expression of IL-2 receptors tended to decrease with the progression of clinical stage. The LAK cells generated by PBM of patients with renal cell carcinoma had significant cytotoxic activity against Daudi cells, ACHN cells and autologous tumor cells, while autologous serum suppressed the expression of IL-2 receptors and the induction of LAK cells in patients with renal cell carcinoam. Furthermore, serum from patients with renal cell carcinoma suppressed the cytotoxic activity of LAK cells generated by PBM from a normal volunteer. These results indicated the presence of immunosuppressive factors in the serum of patients with renal cell carcinoma which impaired the clinical effect of treatment using IL-2 or LAK cells.

Key words: renal cell carcinoma, adoptive immunotherapy, immunosuppressive factor

\footnotetext{
要旨：インターロイキン 2 (IL-2)産生能, IL-2レセプター発現率, および Lymphokine activated killer （LAK）活性を測定し，腎細胞癌患者の免疫能を検討すると共に, IL-2レセプター発現率, LAK 活性に およぽす患者血清の影響を評価した。腎細胞癌患者末梢血単核球のIL-2産生能は非腫瘍群と比較して抑 制されていなかったが, IL-2レセプター発現率は臨床病期の進行とともに低下する傾向がみられた。 LAK 細胞の細胞障害性 (LAK 活性)の検討では, 腎細胞癌患者末梢血単核球より誘導される LAK 細胞 は Daudi 細胞, ACHN 細胞, 自己腫煌細胞に対して明らかな LAK 活性を示した. これに対して腎細胞 癌患者血清は IL-2レセプター発現率, LAK 活性誘導を抑制し,さらに正常人ボランティアの末梢血より 誘導された LAK 細胞の effector phase における活性を抑制した。これらの結果より腎細胞癌患者血清 中には IL-2, LAK 細胞を用いた治療の障害となる免疫抑制因子の存在が示唆された。 キーワード：腎細胞癌, LAK 療法, 免疫抑制因子
} 


\section{緒 言 \\ インターロイキン 2 (IL-2)はリンパ球より産生され} る物質で，その刺激により活性化されたリンパ球は lymphokine activated killer cells（LAK 細胞）と呼 称され，幅広い抗腫瘍活性 (LAK 活性)を示すと報告 されている1). 近年, この現象を利用した養子免疫療法 （LAK 療法）が開始され, 腎細胞癌に対しても有効で あるとされている233. しかしながら，その臨床効果は 未だ充分とは言えず，この一因として悪性腫瘍患者に おける免疫抑制状態や，患者血清中の免度抑制物質の 関与が考えられている。

一方, 腎細胞癌患者においては自然消退例や, 根治 術後長期間を経ての再発例がみられ, さらに他の固形 腫瘍に比較してインターフェロンの有効性が高いこと が示されるなど, 宿主免疫と強く関連すると考兄られ る現象が知られている。

そこで，腎細胞癌患者に拈けるIL-2拉よび LAK 活 性に関連した免疫能を測定するとともに，患者血清が これらの免疫能におよぼす影響について検討した。

\section{対象および方法}

\section{1. 対象}

1）IL-2産生能, レセプター発現率：腎細胞癌と診断 された治療前の 50 ～74歳, 平均 60.1 歳の男性 17 例, 女 性 3 例, 合計20例の患者を腫瘍群とし, さらに Robson 分類により stage I, II の low stage 群, stage III, IV の high stage 群に分類して検討した。また，腎細胞癌 に対して根治的腎摘除術後 6 力月以上経過し, 無治療 で転移, 再発の認められない 50 74歳, 平均 56.4 歳の 男性15例，女性 7 例，合計22例を非腫瘍群とした。

2）LAK 活性に関する検討：腎細胞癌と診断され, 検査時に無治療であった31 79歳，平均55.3歳の男性 18例，女性 2 例，合計20例の患者を腫場群とした。 た, $30 \sim 75$ 歳, 平均 42.7 歳の男性 13 例, 女性 2 例, 合 計15例の血液検査上で異常の認められない健常人また は，尿路結石症患者を対照群とした。

\section{2. 方法}

以下の実験には, リンパ球処理用の培地としては RPMI 1640培地 (GIBCO Laboratories, U.S.A.) を 使用し，培養条件は $5 \% \mathrm{CO}_{2}, 37^{\circ} \mathrm{C} て ゙$ 行った。 また，各 実験はすべて三重測定で施行した。

\section{1) 末梢血単核球 (PBM) 採取}

ヘパリン加末梢血を培地により希釈後, FicollHypaque (Flow Laboratories, Australia) に重層, 400G，30分間遠心により単核球層を採取，さらに培地
で 3 回洗浄してPBM を得た。また同時に血清を採取 し，一部はー $20^{\circ} \mathrm{C}$ に凍結保存した。

2) IL-2産生能

0.5\%BSA (Sigma Chemical Company, U.S.A.) 添加培地を用いて $1 \times 10^{6}$ 個 $/ \mathrm{ml}$ に調製した PBM 浮 遊液 $200 \mu 1$ を96ウェルマイクロプレート内に分注後, 1 $\mu \mathrm{g} / \mathrm{ml}$ の Con-A (E-Y Laboratories, U.S.A.) ととも に24時間培養, PBM の IL-2産生を誘導した。この培養 上清を採取し, 検体として以下の生物学的測定法によ り IL-2産生能を測定した。まず，IL-2依存性の細胞株 CTLL-2細胞 $5 \times 10^{3}$ 個を 96 ウェルマイクロプレート 内に分注, 前述の検体拈よび $50 \mathrm{U} / \mathrm{ml}$ 以下のリコンビ ナント IL-2（rIL-2, S-6820, 塩野義製薬) の希釈系列 とともに 20 時間培養した。さらに $0.25 \mu \mathrm{Ci}$ の $^{3} \mathrm{H}$ thymidine $\left({ }^{3} \mathrm{H}-\mathrm{TdR}\right.$, Amersham, U.K.) を加光 8 時 間培養, セルハーベスター(ACT-96, Biotec, U.S.A.) により細胞を回収，その放射能活性を液体シンチレー ションカウンター（LKB 1216, LKB-produkter AB, Sweden)で測定した。 この IL-2希釈系列と検体の放射 能活性を Probit-analysis ${ }^{4)}$ 行い, IL-2産生能を算出 した。

3） IL-2レセプター（IL-2R）発現率

$20 \%$ 牛胎児血清 (FCS, Flow Laboratories)または, $20 \%$ 自己血清添加培地を用いて $5 \times 10^{5}$ 個 $/ \mathrm{ml}$ に調製 した $\mathrm{PBM}$ 浮遊液 $2 \mathrm{ml}$ を24ウェルマイクロプレート内 に分注, $1 \mu \mathrm{g} / \mathrm{ml}$ の Con-A とともに48時間培養し, PBM に IL-2R を発現させた。 この PBM の Fcレセプ ターを正常ヒト AB 血清 (Flow Laboratories)にてブ 口ック後, 抗 IL-2R 抗体 (IL-2R1, Coulter, U.S.A.) と反応させ， IL-2R 発現率を蛍光抗体法によりフロー サイトメーター（FCM-1，日本分光工業）を用いて測 定した ${ }^{5}$.

4）細胞障害能測定

（1）エフェクター細胞： $1 \times 10^{6}$ 個 $/ \mathrm{ml}$ に調整した $\mathrm{PBM}$ 浮遊液に $2 \mathrm{U} / \mathrm{ml}$ の rIL-2(TGP-3, 武田薬品工業 より供与), $5 \mathrm{U} / \mathrm{ml}$ のヘパリンおよび, $20 \%$ 非動化正常 ヒト $\mathrm{AB}$ 血清または $20 \%$ 非動化自己血清を添加, 5 日 間培養して得られた LAK 細胞をェフェクター細胞と した。

（2）標的細胞：ヒト Burkittリンパ腫由来 Daudi 細胞 (がん研究振興財団より供与), ヒト腎細胞癌由来 $\mathrm{ACHN}$ 細胞および自己腫崵細胞を使用した。

自己腫瘍細胞は, 手術時に得られた腎細胞癌組織を $2 \mu \mathrm{g} / \mathrm{ml}$ のコラゲナーゼ(Type V-S, Sigma), $2 \mathrm{U} / \mathrm{ml}$ 
のヒアルロニダーゼ(Type IV-S, Sigma)，および0.2 $\mathrm{mg} / \mathrm{ml}$ のデオキシリボヌクレアーゼ(Type I, Sigma) 添加培地で 4 時間処理後, $10 \% \mathrm{FCS}$ 加 Dulbecco's Modified Eagle 培地 (DME, Flow Laboratories) で 数日間の初代培養を行って作成した。

細胞の標識は, 各細胞を $10 \% \mathrm{FCS}$ 添加培地中に $1 \times$ $10^{6}$ 個 $/ 0.25 \mathrm{ml}$ で浮遊させ, $50 \mu \mathrm{Ci}$ の $^{51} \mathrm{CrO}_{4}$ (NEN Research Products, U.S.A.)を添加後，90分間培養し た.

(3) ${ }^{51} \mathrm{Cr}$ 放出試験： $1 \times 10^{4}$ 個 $/ 50 \mu 1$ の標的細胞 と 各濃度のエフェクター細胞浮遊液 $100 \mu 1$ を, 96 ウェル マイクロプレート内で混合し 4 時間培養, その培養上 清をExamined release として上清採取システム (Supernatant collection system, Skatoron, Norway) で採取した。同時に， $1 \times 10^{4} / 50 \mu 1$ の標的細胞を $1 \%$ Triton X で溶解した培養上清を Maximum release として，またェフェクター細胞を加えず標的細胞のみ を培養した培養上清を Spontaneous release として， それぞれ採取した。これらの培養上清中の放射能活性 をオートガンマーカウンター(Model 1197, Searl, U. S.A.)にて測定, 以下の計算式を用いて細胞障害能を算 出した.

$\%$ cytotoxicity $=$

Examined release ${ }^{-}-$Spontaneous release

Maximum release-Spontaneous release

なお，試験時の添加血清は LAK 細胞誘導の検討で は10\%非動化正常ヒト AB 血清を，また Effector phase に㧍ける検討では $20 \%$ 非動化対照群血清または 20\%非動化腎細胞癌患者血清を用いた。

5) 統計学的検討

本研究中の統計学的検討はすべて $\mathrm{t}$ 検定により施行 した。

\section{結 果}

1. IL-2産生能々臨床病期 (Fig. 1)

IL-2産生能の平均值は非腫瘍群13.7U, Low stage 群17.6U 扣よび High stage 群 $15.8 \mathrm{U}$ と, 各群間に有 意差はみられず，転移を有する進行性腎細胞癌患者に おいても検出不能な症例から約 $40 \mathrm{U}$ と高值を示す症 例まで広く分布し，一定の傾向は認められなかった。

2. IL-2R 発現率と臨床病期 (Fig. 2, 3)

IL-2R 発現率の平均値は非腫湯群 $29.8 \%$, Low stage 群 $26.2 \%$ 抢よび High stage 群 $22.6 \%$ と臨床病 期の進行とともに低下する傾向がみられ，非腫瘍群と Low stage 群, Low stage 群と High stage 群間には
それぞれ有意差を認めなかったが, High stage 群は非 腫瘍群に比較して $5 \%$ 以下の危険率で有意な低下がみ られた。

さらに, $20 \%$ 自己血清存在下での IL-2R 発現率を 20\%FCS 下での発現率で除し，IL-2R 発現に括よぼす 自己血清添加の影響を検討した。非腫瘍群での平均値 はほぼ1.0であり, 自己血清添加による著明な变動はみ られなかったが, Low stage 群では0.86, High stage 群では 0.67 と臨床病期の進行とともに平均値の低下が みられた。これらの自己血清添加による IL-2R 発現率 の低下は, 非腫瘍群では有意な低下を認めなかったの に対して, Low stage 群では 5 \%以下, High stage 群 に怙いては $1 \%$ 以下の危険率で有意な低下を示した。

3. LAK 活性誘導における血清添加の影響 (Fig. 4) 細胞障害能はェフェクター細胞/標的細胞比 $(\mathrm{E} / \mathrm{T}$ 比） $20: 1$ で検討した。対照群においては $20 \%$ 非動化 正常ヒト $\mathrm{AB}$ 血清下で誘導された LAK 細胞の各々の 標的細胞に対する細胞障害能は平均值でみると,

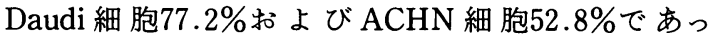
た。これに対して，20\%非動化自己血清存在下に誘導 された LAK 細胞の細胞障害能は, Daudi 細胞で $73.7 \%, \mathrm{ACHN}$ 細胞で $49.5 \%$ であり自己血清添加によ る有意な变動はみられなかった。一方, 腫場群におい ては，20\%非動化正常ヒト AB 血清下で誘導された LAK 細胞の各々の標的細胞に対する細胞障害能は平

Fig. 1 Comparative study on the production of IL2 by clinical stage in the peripheral blood mononuclear cells. Bars indicate mean $\pm \mathrm{SD}$.

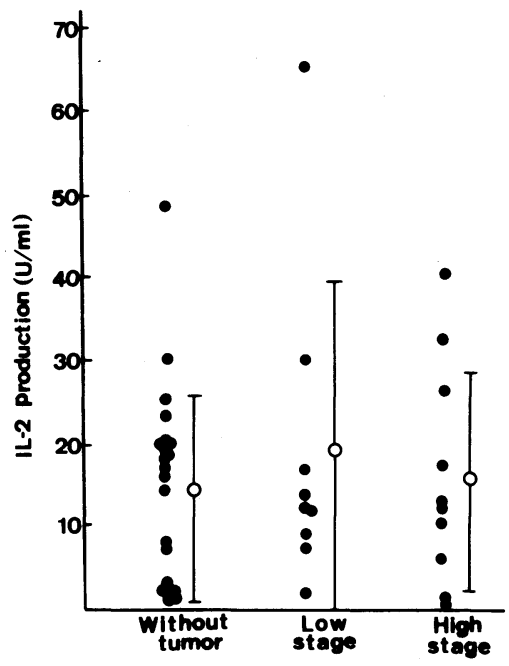


Fig. 2 Comparative study on the expression of IL. 2 receptor by clinical stage in the peripheral mononuclear cells. The levels of expression of IL2 receptor in patient with high stage renal cell carcinoma were significantly lower than those in patient without resal cell carcinoma $(p<0.05)$. Bars indicate Mean \pm SD.

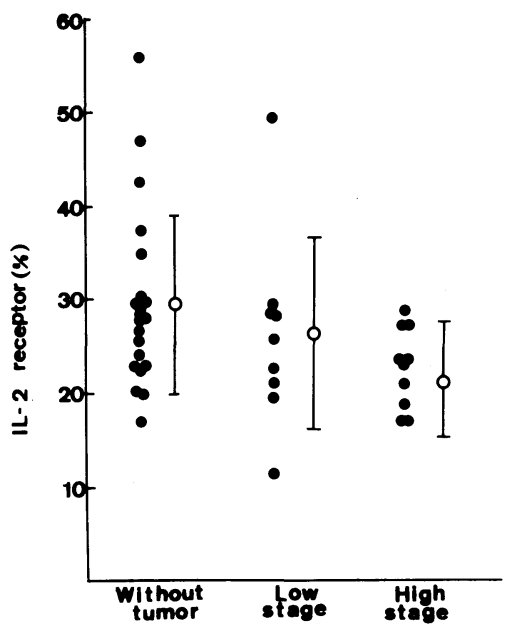

均値でみると, Daudi 細胞 $82.2 \%, \mathrm{ACHN}$ 細胞 $65.2 \%$ および自己腫瘍細胞 $40.8 \%$ であった。これに対して, $20 \%$ 非動化自己血清存在下に誘導された LAK 細胞の 細胞障害能は, Daudi 細胞で13例中12例, ACHN 細胞 で14例中12例，自己腫瘍細胞においても 8 例中 7 例で 低下がみられ，各々平均值で, $72.6 \%, 52.4 \%, 31.1 \%$ であった。これらは, Daudi 細胞では $1 \%$ 以下, ACHN 細胞怙よび自己腫瘍細胞では $5 \%$ 以下の危険率で有意 な低下であった。

4. $\mathrm{LAK}$ 細胞の細胞障害能に及ぼす血清添加の影 響（Fig. 5)

健常人ボランティア末梢血より誘導された LAK 細 胞をェフェクター細胞とし， Daudi 細胞を標的細胞と して用いた。 $\mathrm{E} / \mathrm{T}$ 比は生体内の条件を考慮し $2 ： 1$ で LAK 活性を検討した.この結果, Daudi 細胞に対する 細胞障害能は, $20 \%$ 非動化腎細胞癌患者血清添加群で の平均值は $9.9 \%$ であり, $20 \%$ 非動化対照群血清添加群 での平均値 $12.7 \%$ に比較して $5 \%$ 以下の危険率で有意 な低下であった。

\section{考 察}

悪性腫瘍患者においては種々の免度抑制が存在する とされており ${ }^{6)}$ 腫瘍がその宿主免疫監視機構を逃れ て発育や転移を生じる過程に関与すると考兄られてい
Fig. 3 Effect of autologous serum on the expression of IL-2 receptor. The levels of expressions of IL-2 receptor were significantly suppressed by the addition of autologous serum in patient with low stage renal cell carcinoma $(\mathrm{p}<0.05)$ and in patient with high stage renal cell carcinoma $(\mathrm{p}<$ 0.01 ).

Ratio $=$ Expression of IL-2 receptor with autologous serum/Expression of IL-2 receptor with normal human $\mathrm{AB}$ serum. Bars indicate Mean \pm SD.

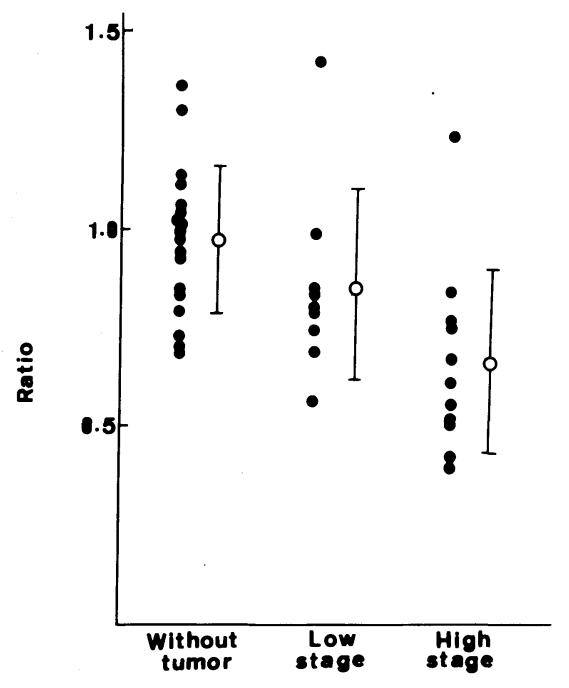

る.この原因としては腫瘍による免疫抑制物質の産 生7や, サプレッサーマクロファージ, サプレッサーT 細胞を介した抑制(8)などが考えられ，これらの因子を 含む患者腫場の抽出液9)や血清 ${ }^{10111)}$ によって種々の免 疫反応が抑制されることが報告されている。かような 免疫抑制は, 近年開始された IL-2, LAK 細胞を用いた 臨床治療に颃いても今後の課題となっている。

IL-2は主としてへルパーT 細胞より産生され, Con A, PHA といった mitogenやアロ抗原刺激によって その産生は増強される。生体内で産生された IL-2は細 胞障害性を持つリンパ球の誘導を介して抗腫癔作用を 発現すると考えられることより, 担癌患者の免疫能評 価法の一つとして IL-2産生能が測定されている。すな わち, 担癌患者では健常人に比較して IL-2産生能は低 下しているとしたもの ${ }^{12}$ p不変であるとした報告 ${ }^{13)}$ が みられる，著者の腎細胞癌患者における検討では非腫 瘍群に対して顕著な差はみられず，また臨床病期の進 行とも無関係であった。この結果について考慮すべき 
Fig. 4 Effect of autologous serum (AT) on the induction of LAK activity against Daudi cells, ACHN cells and autologous tumor cells (ATT) in patients with renal cell carcinoma. In patient with renal cell carcinoma, the levels of the percentage of specific lysis were significantly suppressed against Daudi cells $(\mathrm{p}<0.01), \mathrm{ACHN}$ cells and autologous tumor cells $(\mathrm{p}<0.05)$. Bars indicate Mean $\pm \mathrm{SD}$.

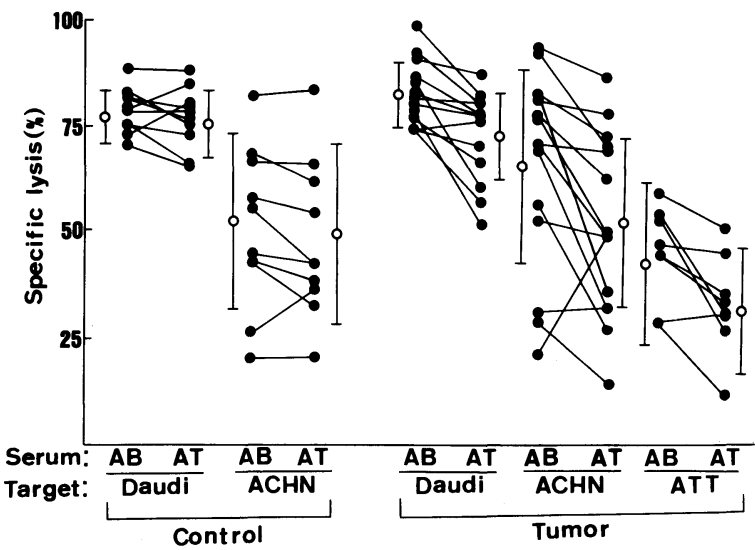

点の一つは, 今回検討した非腫瘍群は検討時には腫瘍 は認めないものの, 一度は悪性腫瘍の発生した個体で あり，健常人における IL-2産生能と分布が異なる可能 性である。しかしながら, 担癌患者で IL-2産生能の低 下を示した報告の多くは進行性悪性腫瘍においてであ り，著者らの検討では進行性腎細胞癌患者においてさ えIL-2産生能が保持されている症例も多くみられ, 腎 細胞癌患者では特異的な低下は示さないと考えられ た。また実験条件について，リンパ球のレクチン刺激 は24時間では不充分であり，リンパ球自身が IL-2の利 用を開始する48時間での検討においては, 担癌患者の IL-2産生能は健常人のそれと比較して低下を示す可能 性があるとした報告もみられ ${ }^{13)}$, 今後の検討を要する 点であろう.

IL-2R には高親和性（Kd 値約0.01nM）と低親和性 レセプター（P55, Tac 抗原, $\mathrm{Kd}$ 值約 $10 \mathrm{nM})$ の存在 が知られており，このうち低親和性レセプターについ ては cDNA の同定, アミノ酸配列の決定, 抗 Tac 抗体 による定量などの種々の検討が進められてきた ${ }^{14)}$.さ らに, ${ }^{125} \mathrm{I}$ 標識 IL-2を用いた解析によって, IL-2と中等 度の親和性を持ち, 抗 $\mathrm{Tac}$ 抗体と反応しない分子量 70〜75Kd の中親和性レセプター(P75, Kd 值約1nM) の存在が報告され，高親和性レセプタ一はこれら P55
Fig. 5 Effect of serum on the cytolytic activity of LAK cells. The levels of the perecentage of specific lysis were significantly suppressed by the addition of serum from patient with renal cell carcinoma $(p<0.05)$. Bars indicate Mean \pm SD.

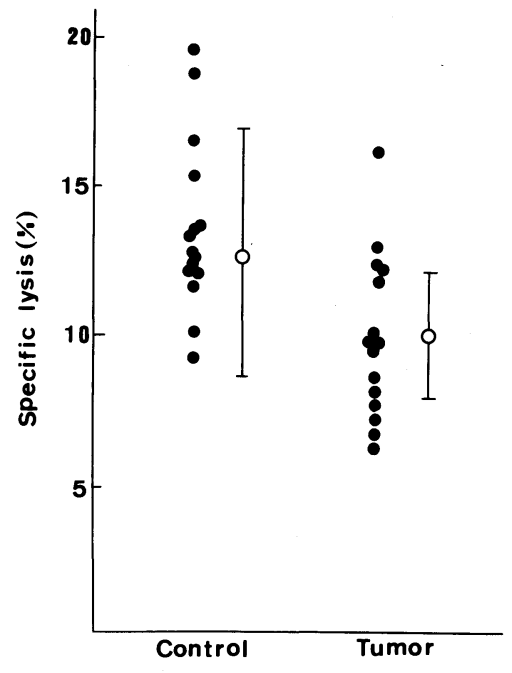

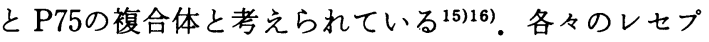
ターの機能的役割についてはな打不明な部分も多い が，P55にはキナーゼ活性を持つドメインが存在しな い事より, 直接細胞内にシグナルを伝達する機能はな く，高親和性レセプターの形成を通じて作用している とされている. また抗 Tac 抗体で処理後のリンパ球に IL-2を作用させると, 早期には LAK 活性の上昇がみ られる.しかし長期にわたる活性の維持は不可能で, リンパ球の増殖も示さないとの実験結果より，P75は 単独で細胞内ヘシグナルを伝達し細胞の分化を促進し 得るが，細胞の増殖には高親和性レセプターの存在が 必要であると報告されている ${ }^{17)}$. 以上の事より, 今回用 いた抗 Tac 抗体の IL-2R1は低親和性レセプター （P55）扣よび高親和性レセプター（P55とP75の複合 体) とは反応するが P75とは反応せず，これによる IL2R システム細部の解析は困難と考えられるが, 臨床的 な面よりみると Tac 抗原陽性細胞は活性化 T リンパ 球で, その増加は免疫能の亢進を示すとされ ${ }^{18)}$, 本法に よる IL-2R 発現率は細胞性免疫の指標として用いら れている，その一つとして悪性腫瘍患者末梢血中リン パ球における解析が行われており，担癌患者では臨床 病期の進行とともに IL-2R (Tac 抗原) の発現率が低 下するとの報告もみられる ${ }^{19)}$ ，今回の著者の腎細胞癌 患者における検討では，同様に臨床病期の進行ととも 
に患者末梢血中単核球の IL-2R (Tac 抗原) 発現率の 低下がみられ,さらに患者自己血清の添加により IL-2 $\mathrm{R}$ 発現率の低下が認められた。この結果から，腎細胞 癌患者における IL-2R を介した免疫抑制状態の存在 のみならず，患者血清中の IL-2R の発現を抑制する免 疫因子の存在が推察された。そこで, 臨床治療上の問 題となる LAK 細胞におよぼす患者血清の影響につい て検討した。

現在行われている LAK 療法では, in vitro で誘導さ れた LAK 細胞とともに，患者に投与される IL-2に よって in vivoでも誘導された内因性 LAK 細胞も抗 腫湯効果発現に動いていると考兄られ，これはIL-2単 独投与のみでも臨床効果が得られた症例があることに より推測される ${ }^{20)}$.このことは LAK 療法に際しての 悪性腫瘍患者の免疫抑制作用としては, LAK 細胞の 誘導, Effector phase 双方における抑制を考慮する必 要性を示している. in vitroに打ける LAK 細胞の誘導 に関しては従来より，悪性腫瘍患者の末梢血リンパ球 より誘導される LAK 細胞は健常人のそれと同等な活 性を示すとされており ${ }^{21)}$, 著者の検討においても, 正常 ヒト $\mathrm{AB}$ 血清存在下に腎細胞癌患者の $\mathrm{PBM} よ り$ 誘導 された LAK 細胞は Daudi 細胞, ACHN 細胞に対し て正常人と同等な細胞障害性を, 自己腫瘍細胞に対し ても24〜56\%と比較的良好な細胞障害性を認めた。こ れらの結果より，LAK 療法に拈いて腎細胞癌患者の 自己末梢血中より誘導した LAK 細胞を用いても，充 分に臨床効果を期待し得ると思われた。これに対して, 悪性腫瘍患者血清は自己リンパ球の LAK 細胞への誘

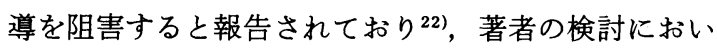
ても腎細胞癌患者血清は LAK 細胞の誘導および, Effector phase での LAK 細胞の腫崵細胞に対する細 胞障害に抑制的に働くものと考えられた.

以上より腎細胞癌患者血清中には IL-2, LAK 細胞 に関する免疫抑制因子が存在し, 臨床的に試みられて いる LAK 療法に際しての問題点となるものと考えら れた。

\section{結語}

腎細胞癌患者末梢血中単核球における IL-2産生能, レセプター発現率, LAK 活性および患者血清中のこ れら免度反応の抑制因子について検討した。

1. IL-2産生能は腫湯の存在の有無, 臨床病期による 差は認めず, 腎細胞癌患者に抢いては特異的な変動は 示さなかった。

2. IL-2R 発現率は臨床病期の進行とともに低下す
る傾向をみとめ，また患者自己血清は IL-2R 発現率を 抑制した。

3. Daudi 細胞, ACHN 細胞および自己腫瘍細胞に 対する LAK 活性の誘導は患者自己血清により抑制さ れた。

4. Effector phase に患者血清が存在すると LAK 活性の抑制がみられた。

本論文の要旨の一部は第75回および76回日本泌尿器科学 会総会において報告した。稿を終えるにあたり御指導およ び御校閱を賜りました恩師碓井 亞教授に深甚なる謝意を 表します。 また, 種々の御教示を賜りましたマッダ病院泌尿 器科中野 博博士, 中本貴久博士に深謝いたします。

\section{文 献}

1) Grimm, E.A., Mazumder, A., Zhang, H.Z. and Rosenberg, S.A. : Lymphokine-activated killer cell phenomenon: Lysis of natural resistant fresh solid tumor cells by interleukin 2 activated autologous human peripheral blood lymphocytes. J. Exp. Med., 155, 1823-1841, 1982.

2) Wang. J., Walle, A., Gordon, B., Novogrodsky, A., Suthanthiran, M., Rubin, A.L., Morrison, H., Silver, R.T. and Stenzel, K.H.: Adoptive immunotherapy for stage IV renal cell carcinoma: A novel protocol utilizing periodate and interleukin-2-activated autologous leukocytes and continuous infusions of low-dose interleukin-2. Am. J. Med., 83, 1016-1023, 1987.

3) Fisher, R.I., Coltman, C.A. Jr., Doroshow, J.H., Rayner, A.A., Hawins, M.J., Mier, J. W., Wiernik, P., Mcmannis, J.D., Weiss, G.R., Margolin, K.A., Gemlo, B.T., Hoth, D.F., Parkinson, D.R. and Paietta, E. : Metastatic renal cancer treated with interleukin-2 and lymphokine-activated killer cells. Ann. Int. Med., 108, 518-523, 1988.

4) Gillis, S., Ferm, M.M., Ou, W. and Smith, K.A.: $T$ cell growth factor. Parameters of production and a quantitative microassay for activity. J. Immunol., 120, 2027-2032, 1978.

5) Lanier, L.L. and Warner, N.L.: Paraformaldehyde fixation of hematopoietic cells for quantitative flow cytometry analysis. J. Immunol. Methods, 47, 25-30, 1981.

6) 中本貴久, 薄井昭博, 池本秀昭, 中野 博, 碓井 亞：堅細胞癌患者の免疫能に関寸る臨床的検討。 西日泌尿．50，1135-1141，1988.

7) Hersey, P., Bindon, C., Czerniecki, M., Spurling, A., Wass, J. and Mccarthy, W.H.: Inhibition of interleukin 2 production by factors released from tumor cells. J. Immunol., 131，2837-2842, 
1983.

8) Thomas, R.: Role of suppressor cells in depression of in vitro lymphoproliferative responses of lung cancer and breast cancer patients. J.N.C.I., 61, 1001-1005, 1978.

9) Mohagheghpour, N., Parhami, B., Dowlatshahi, K., Kadjehnouri, D., Elder, J.H. and Chisari, F. : Immunoregulatory properties of human esophageal tumor extract. J. Immunol., 122, 1350-1358, 1978.

10) Roth, J.A., Grimm, E.A., Gupta, R.K. and Ames, R.S. : Immunoregulatory factors derived from human tumors: 1. Immunologic and biochemical characterization of factor that suppress lymphocyte proliferative and cytotoxic responses in vitro. J. Immunol., 128, 1955-1954, 1982.

11）小野 浩：泌尿性器悪性腫場患者の免疫能に関す る研究：第 2 編. 血清蛋白の異常の免度能に及ほ 寸影響. 日泌尿会誌，72，1078-1091，1981。

12) Rey, A., Klein, B., Rucheton, M., Caraux, J. Zagury, D., Thierry, C. and Serrou, B.: Human autologous rosettes: IV. Their relation with interleukin 2 activity production and natural killer cells in cancer patients. Cell Immunol., 86, 155-164, 1984.

13) Wanebo, H.J., Pace, R., Hargett, S., Katz, D. and Sando, J.: Production and response to interleukin-2 in peripheral blood lymphocytes of cancer patients. Cancer, 57, 656-662, 1986.

14) Taniguchi, T., Matsui, H., Fujita, T., Takaoka, C., Kashina, N., Yoshimoto, R. and Hamuro, J. : Structure and expression of a cloned cDNA for human interleukin-2. Nature, 302, 305-307, 1983.

15) Sharon, M., Klausner, R.D., Cullen, B.R., Chizzonite, R. and Leonard, W.J.: Novel interleukin-2 receptor subunit detedted by cross-linking under high-affinity conditions. Science, 234, 859-863, 1986.
16) Teshigawara, K., Wang, H., Kato, K. and Smith, K.A.: Interleukin 2 high-affinity receptor expression requires two distinct binding proteins. J. Exp. Med., 165, 223-238, 1987.

17) Owen-schaub, L.B., Loudon, W.G., Yagita, M. and Grimm, E.A.: Functional differentiation of human lymphokine-activated killing (LAK) is distinct from expansion and involves dissimilar interleukin 2 receptors. Cell Immunol., 111, 235-246, 1988.

18) Uchiyama, T., Nelson, D., Fleisher, T.A. and Waldmann, T.A.: A monoclonal antibody (anti-Tac) reactive with activated and functionally mature human $T$ cells : 2 . Expression of Tac antigen on activated cytotoxic killer $\mathrm{T}$ cells, suppressor cells, and on one of two types of helper T cells. J. Immunol., 126, 1398-1403, 1981.

19) Hakim, A.A.: Peripheral blood lymphocytes from patients with cancer lack interleukin-2 receptors. Cancer, 61, 689-701, 1988.

20) Rosenberg, S.A., Lotze, M.T., Muul, L.M., Chang, A.E., Avis, F.P., Leitman, S., Linehan, W.M., Robertoson, C.N., Lee, R.E., Rubin, J.T., Seipp, C.A., Simpson, C.G. and White, D.E. : A progressive report on the treatment of 157 patients with advanced cancer using lymphokine-activated killer cells and interleukin-2 alone. N. Eng. J. Med., 313, 1485-1492, 1985.

21) Lotze, M.T., Grimm, E.A., Mazumder, A., Strausser, J.L. and Rosenberg, S.A.: Lysis of fresh and cultured autologous tumor by human lymphocytes cultured in T-cell growth factor. Cancer Res., 41, 4420-4425, 1981.

22) Itoh, K., Tilden, A.B. and Balch, C.M. : Role of interleukin 2 and a serum suppressive factor on the induction of activated killer cells cytotoxic for autologous human melanoma cells. Cancer Res., 45, 3173-3178, 1985.

（1990年 3 月 15 日受理） 